\title{
Sex Chromosome Mosaicisms in Five Swine Intersexes
}

\author{
Yoshiro Toyama* \\ Department of Veterinary Anatomy, Faculty of Agriculture, \\ Tokyo Noko University, Fuchu-shi, 183, Tokyo.
}

(Received March 19, 1974)

\begin{abstract}
Chromosome investigations were carried out on five cases of intersex swine. Four cases showed the $\mathrm{XX} / \mathrm{XY}$ mosaicism in hemopoietic cells, and one of these showed the normal female karyotype in the skin and the kidney cells. The last one showed the $\mathrm{XX} / \mathrm{XXY}$ mosaicism in both hemopoietic and non-hemopoietic tissues. This case has not been described in swine previously. The mechanisms of the chromosomal mosaicism were disscussed.
\end{abstract}

Since Makivo et al.1) have reported the chromosome constitution of an intersex swine, more than eighty cases of intersex swine with or without chromosomal abnormalities have been pub. lished ${ }^{2-17}$ ). MCFEE et al. ${ }^{2)}$ have first reported the sex chromosome mosaicism (XX/XY) in an intersex swine, and five additional cases of this type of the mosaicism have been described ${ }^{3-6)}$. The present paper deals with four additional cases of the $\mathrm{XX} / \mathrm{XY}$ intersex swine and one case of the $\mathrm{XX} / \mathrm{XXY}$ intersex swine, not previously described in this species. Anatomical findings of the genital organs as well as cytogenetical findings were described brietly.

\section{Materials and Methods}

The five intersex swine were collected at farms or research stations of animal industry near Tokyo in recent six years.

For the leukocyte culture, $1 \mathrm{~m} l$ of heparinized peripheral blood was incubated under the sterile condition in $10 \mathrm{ml}$ of the tissue culture medium (TC-199) containing $0.2 \mathrm{ml}$ of phytohemagglutinin-M (Difco) at $38^{\circ} \mathrm{C}$ for three days. Heparinized bone marrow fluid $(0.2 \mathrm{~m} l$ ) was also incubated under the sterile condition in $10 \mathrm{ml}$ of the medium (TC-199; $8 \mathrm{ml}$, calt serum; $2 \mathrm{~m} l)$ at $38^{\circ} \mathrm{C}$ for one day.

For chromosome analysis, the cell division was arrested at the metaphase with $0.2 \mathrm{ml}$ of col. chicine at the proportion of $50 \mu \mathrm{g} / \mathrm{ml}$. One percent sodium citrate or $10 \%$ calf serum was used for the hypotonic solution. After fxation in Carnoy's solution, cells were mounted on the slide glass and dried according to the air-drying method ${ }^{18)}$ and stained with Giemsa's solution.

Further, for the chromosomes in non-hemopoietic cells, the skin of the ear tip about the size of $1 \mathrm{~cm}^{2}$ and small pieces of the kidney were removed. The blocks were minced with a razor blade into inoculums, which were planted on the surface of the culture bottle directly. After half drying for 10 to 20 minuites, $10 \mathrm{ml}$ of the tissue culture medium ( $\mathrm{TC}-199 ; 8 \mathrm{~m} l$, calf serum; $2 \mathrm{~m} l$ and kanamycine; $1 \mathrm{mg}$ ) was overlayed. After the incubation of about seven days at $38^{\circ} \mathrm{C}$, growing cells were treated with colchicine in a final concentration of $1 \mu \mathrm{g} / \mathrm{m} l$ for 2.5 hours, and then with $0.3 \%$ trypsin for 30 minutes to remove the cells from the wall of the bottle. The

* Present Address: Department of Anatomy, School of Medicine, Chiba University, Chiba-shi, 280

Jap. J. Zootech. Sci., 45, (10): 551-557.

1974. 10. 


\section{TOYAMA}

hypotonic treatment, fixation and staining were similar to those described above.

\section{Results}

No. 1. Yorkshire. Age of a month. The animal was $40 \mathrm{~cm}$ in crown-rump length (CRL). It was the smallest in the littermates. It had the vulva and the scrotal hernia, in which no gonads were located. The vagina, uterus and gonads were not observed in the abdominal cavity. The cranial end of the spindle-shaped urinary bladder was connected to the peritoneal surface of the abdominal wall by the remnant of the alantois duct. The outer orifice of the bladder was dilated forming the vestibulum. The kidneys and the ureters were edematous and about two times as large as normal in size (Fig. 1).

The sex chromosome constitution in hemopoietic cells: $\mathrm{XX} / \mathrm{XY}(16 / 15)$.

No. 2. Landrace. Age of two weeks. CRL: $38 \mathrm{~cm}$. The animal was the smallest in the littermates. It showed similar anatomical features to those of No. 1.

The sex chromosome constitution of hemopoietic cells: $\mathrm{XX} / \mathrm{XY}$ (23/15). (Fig. 7).

No. 3. Landrace. Age of two months. CRL: $85 \mathrm{~cm}$. The animal showed the normal growth rate but had neither the normal vulva nor the penis. The enlarged clitoris was remarkable in the external genital region. The external urethral orifice opened dorsal to the enlarged clitoris. Bilateral testes with epididymides were attached to the cranial ends of the uterine horns by the spermatic cord-like ligaments. The lumen of the poorly developed vagina was constricted at about $2 \mathrm{~cm}$ cranial to the supposed vulva, and connected to the urethra (Fig. 2). Histologically, the testis showed the poorly developed seminiferous tubules. The germinal epithelium consisted of only immature sustentacular cells. The interstitial cells seemed to be normal.

The sex chromosome constitution in hemopoietic cells: $\mathrm{XX} / \mathrm{XY}$ (45/9).

No. 4. Mixed breed. Age of six months. CRL: $125 \mathrm{~cm}$. The growth rate appeared to be normal for the age. The enlarged clitoris-like process and the scrotum of the subnormal size were observed in the external genital region. Bilaterally descended testes with epididymides were palpable in the scrotum (Fig. 3). The lumen of the cranial one fourth of the urethra, which opened dorsal to the enlarged clitoris-like organ, was dilated presenting the poorly developed vagina. The seminal vesicle-like organs were observed (Fig. 4). In histological sections of the testis, the wall of each tubule consisted of a single layer of cuboidal cells, but the interstitial cells seemed to be normal (Fig. 5).

The sex chromosome constitution in the skin and kidney cells: XX (52), (23) respectively. The sex chromosome constitutiton in hemopoietic cells: $\mathrm{XX} / \mathrm{XY}(107 / 61)$.

No. 5. Landrace. Age of four months. CRL: $91 \mathrm{~cm}$. The animal showed the normal growth rate and had the similar external genital features to those of No. 3. It had bilateral ovotestes. Small eight to ten Graafian folliculi were found on the surface of each ovarian part. The lumen of the uterus dilated with a fluid as it it were pregnant. The lumen of the poorly developed vagina was constricted at about $1.5 \mathrm{~cm}$ cranial to the supposed vulva, and connected to the urethra (Fig. 6). The connective tissue divided the smaller ovarian part from the larger testicular one, where poorly developed seminiferous tubules were found.

The sex chromosome constitution in the skin and kidney cells: $\mathrm{XX} / \mathrm{XXY}(32 / 5),(29 / 7)$ respectively. The sex chromosome constitution in hemopoietic cells: $\mathrm{XX} / \mathrm{XXY}$ (38/5). (Fig. 8).

The autosomes in these five cases appeared to be normal both in figure and number. 


\section{Discussion}

The chromosome number of 38 in the domestic swine has been established ${ }^{1,19-21)}$. Since Makino et al.1) have first reported an intersex swine with the normal female karyotype, more than seventy-two cases of intersex swine with the normal female karyotype ${ }^{6,7,9-17)}$ and eight cases with the chromosomal abnormality ${ }^{2-8}$ ) have been reported. More cases of the intersex swine with the normal female karyotype were also observed (Y. OMURA, personal communication). On the other hand, in the cases of cattle freemartin, it is widely accepted that the female co-twin shows the $\mathrm{XX} / \mathrm{XY}$ mosaicism as well as the male co-twin shows. This suggests that the etiology of the most cases in the intersex swine (i.e. of the intersex swine with the normal female karyotype) is different from that of the freemartin in cattle. Among the intersex swine with the chromosomal abnormality, McFeE et al. ${ }^{2)}$ have first reported a case of the $\mathrm{XX} / \mathrm{XY}$ sex chromosome mosaicism in cultured leukocytes. Since then five cases of the intersex swine showing the $\mathrm{XX} / \mathrm{XY}$ mosaicism have been reported ${ }^{3-6}$. In addition the cases of the intersex swine with the XXY sex chromosome constitution have been reported. ${ }^{7,8)}$

According to previous papers, there are many variations in intersexiality of the swine. Among

\section{Explanation of the figures}
c: enlarged clitoris
k: kidney,
of: ovotestis,
r: rectum,
s: seminal vesicle-like organ.

¥: testis with epididymis,

u: uterus,

Ub: urinary bladder,

w: abdominal wall,

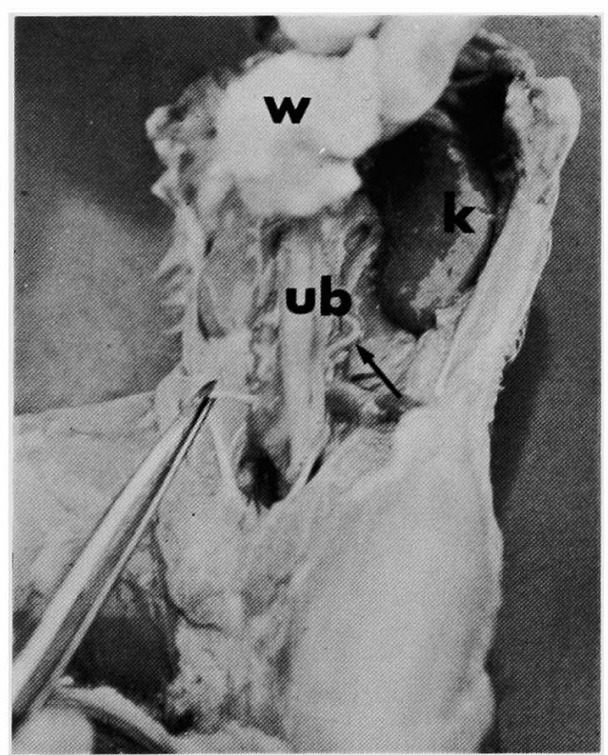

Fig. 1. The photograph shows no internal genital organs. The spindle-shaped urinary bladder attaches to the abdominal wall. The kidneys and ureter (arrow) are edematous. (Case No. 1).

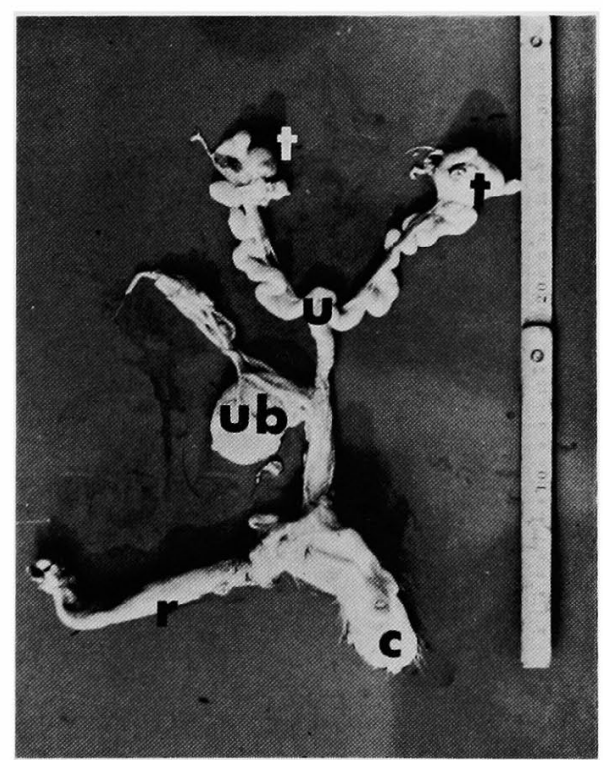

Fig. 2. The genital organs of case No. 3. The intra-abdominal testes attach to the cranial ends of the uterine horns. 
them, it is interesting to note a report of a phenotypic male swine with normal female karyotype $^{10)}$ and other reports of true hermaphrodites with female looks and functions to sustain their embryos until the late stage of gestation ${ }^{22-24}$. Thus, it is generally accepted that the corelation between the organogenesis and the chromosome constitution is obscure in swine intersexes.

Following explanations on the mechanisms of the occurrence of the $\mathrm{XX} / \mathrm{XY}$ mosaicism in swine are presented.

1) The double fertilization or the fusion of $\mathrm{XX}$ and $\mathrm{XY}$ blastocysts proposed by BASRUR and KaNAGAWA ${ }^{6}$.

2) The divisional error of the sex chromosomes such as, a normal male zygote $(\mathrm{XY}) \rightarrow$ appearance of an $\mathrm{XO}$ cell in the $\mathrm{XY}$ zygote by the deletion of the $\mathrm{Y}$ chromosome $(\mathrm{XO} / \mathrm{XY}) \rightarrow$ appearrance of an $\mathrm{XX}$ cell line by the non-disjunction of the $\mathrm{X}$ chromosome in the $\mathrm{XO}$ cell $(\mathrm{XX} / \mathrm{XY})$. Such a condition is known in man (OHNo, personal communication).

In the case of either of these mechanisms, the mosaicism can be observed through the whole body of the subject animal.

3) The intra-uterine vascular anastomosis by VoGT4). That is, in the case of the heterosexual twin embryos, the primitive hemopoietic cells of the co-twin of the opposite sex can invade into the subject animal through the anastomosis. The mosaicism, therefore, appears only in hemopoietic cells and the chromosome complement of other tissues shows its genetic sex. If the anastomosis

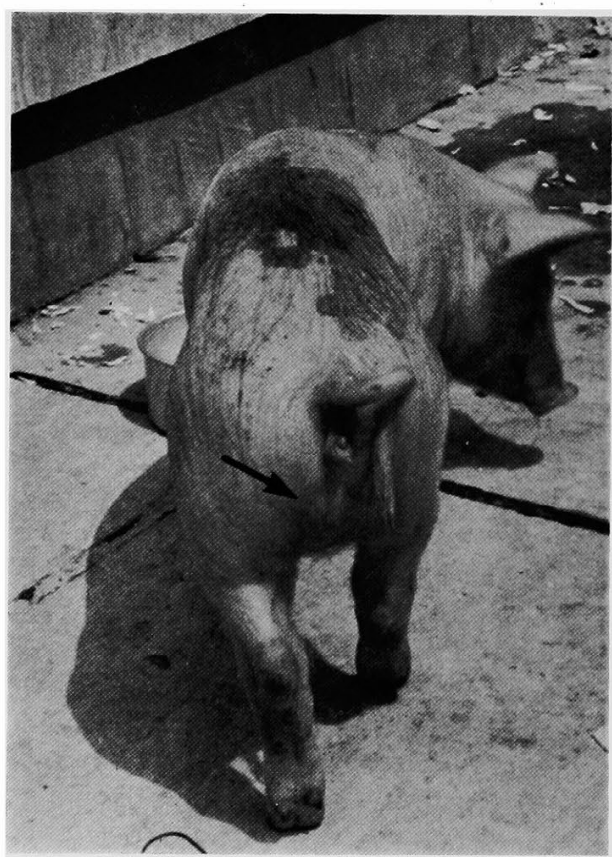

Fig. 3. External genitalia of case No. 4. The enlarged clitoris-like process and the small scrotum (arrow) are observed.

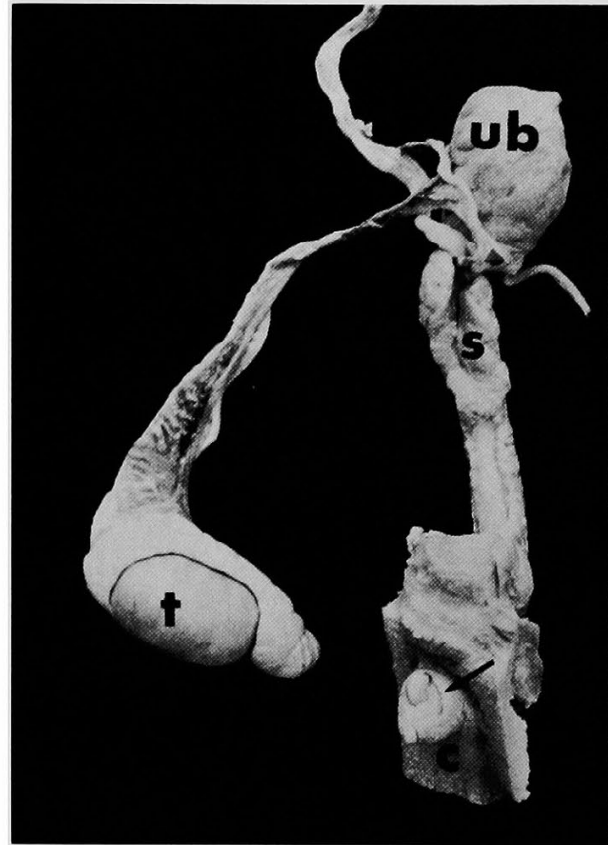

Fig. 4. The genital organs of case No. 4. The left testis is out of the figure. The right testis with the epididymis, seminal vesicle-like organs and enlarged clitorislike organ are seen. The urethra is enlarged in diameter and reveals the vagina-like architecture. The arrow shows the external orifice of the urethra which opens dorsal to the enlarged clitoris. 
Sex Chromosome Mosaicims in Swine Intersexes

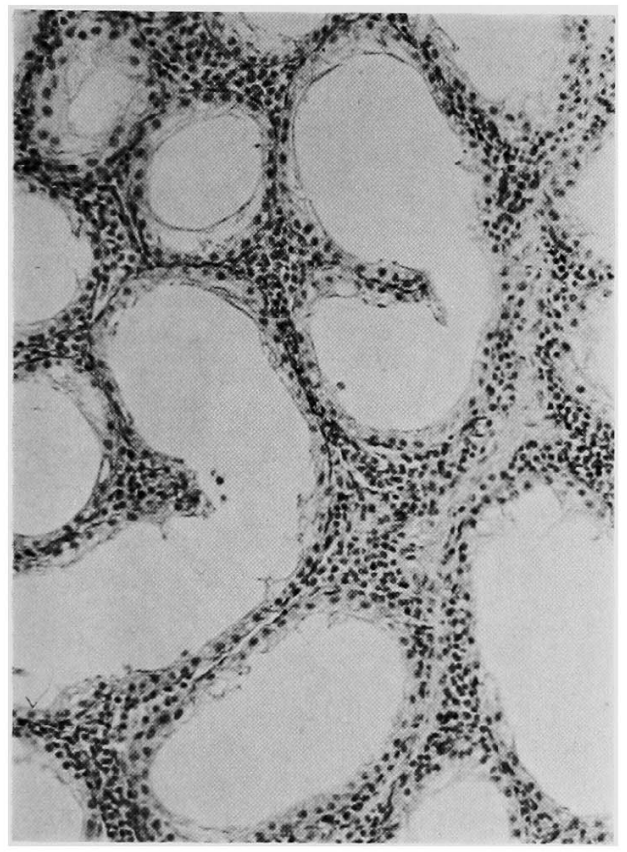

Fig. 5. Photomicrograph of the left testis in case No. 4. The seminiferous epithelium has no germinal cells. The single layer of the cuboidal cells are observed in each tubule.

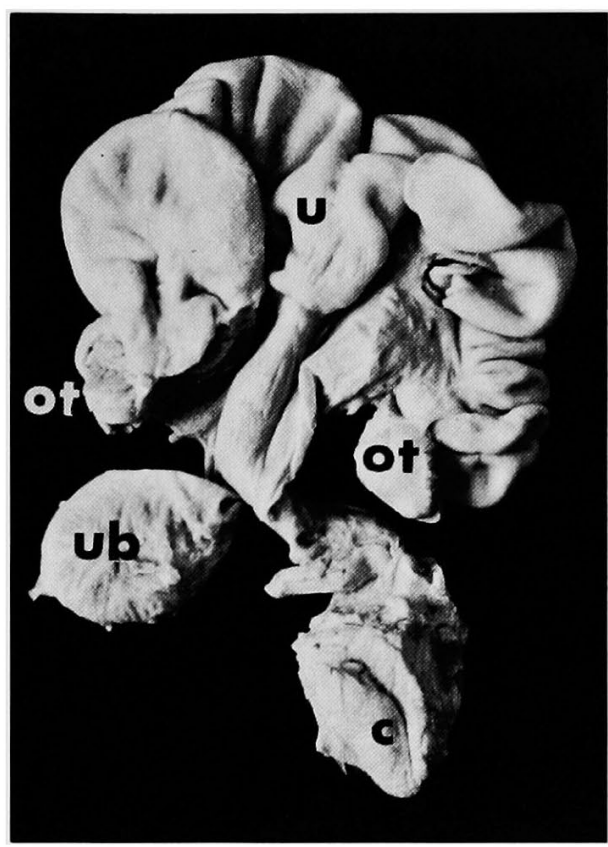

Fig. 6. The genital organs of case No. 5. The lumen of the uterus is dilated abnormally. Bilateral ovotestes are shown.

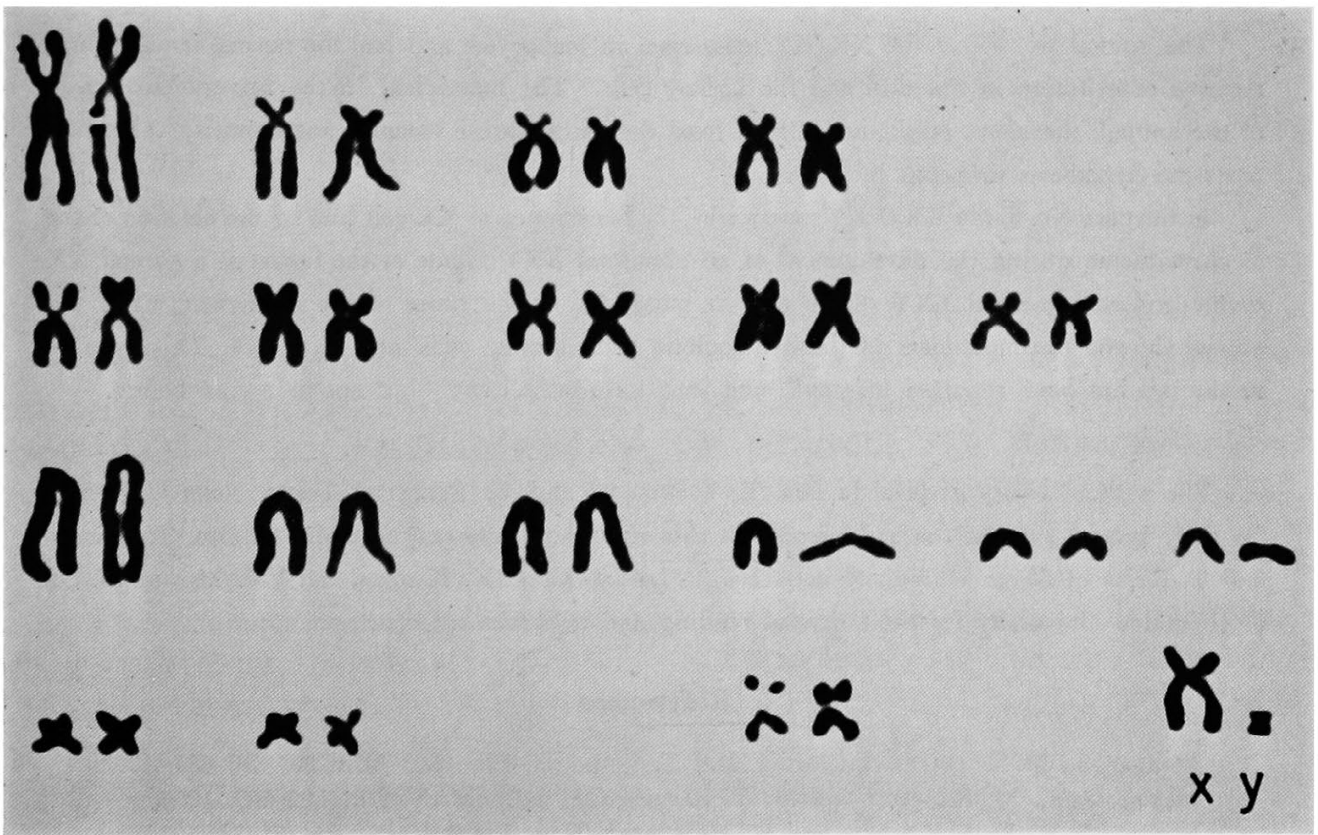

Fig. 7. A karyotype of a cultured leukocyte in case No. $2 ; 38$, XY. 


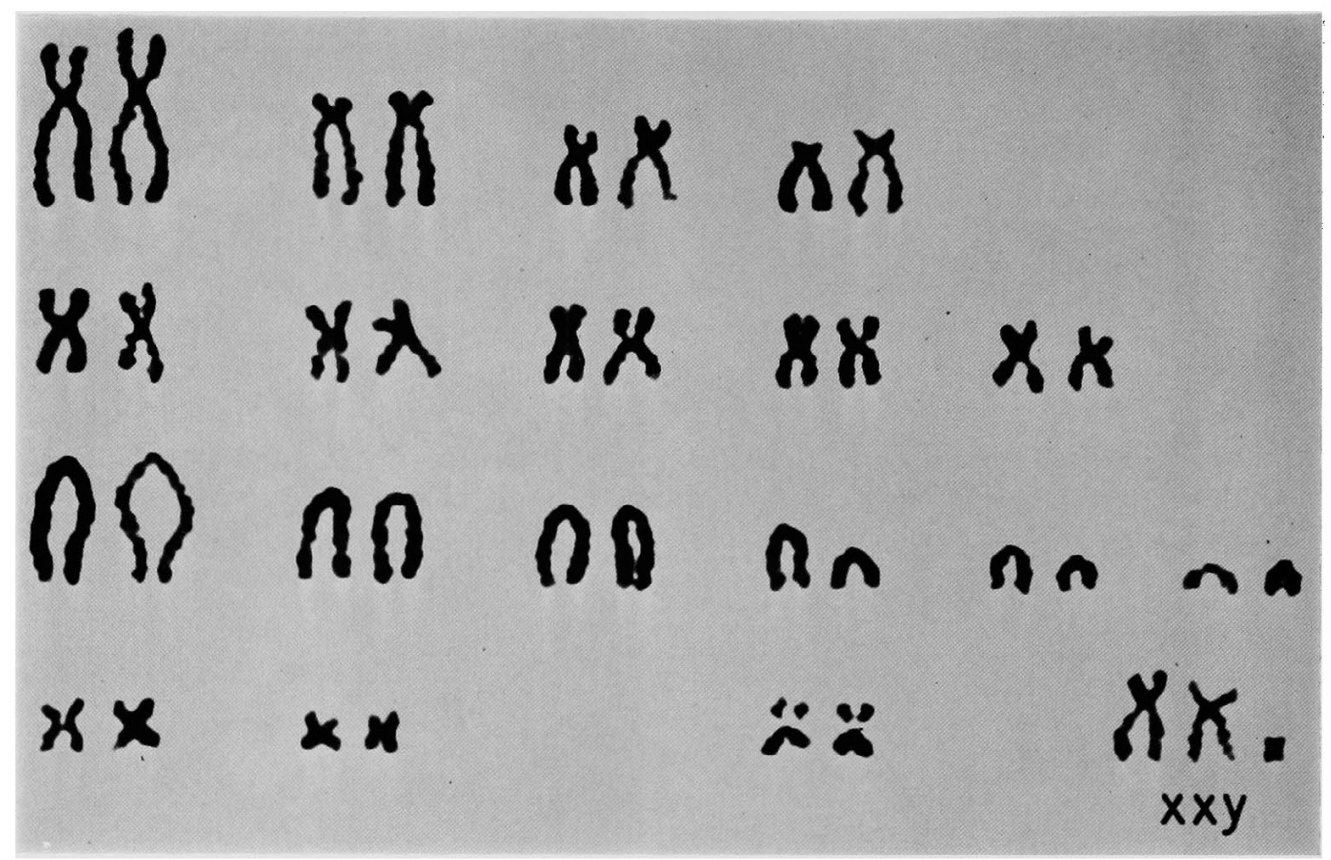

Fig. 8. A karyotype of a cultured skin cell in case No. 5; 39, XXY.

occurs earlier enough than the primordial germ cells reach the genital ridges, the cells of the gonads in the subject animal may also show the $\mathrm{XX} / \mathrm{XY}$ mosaicism ${ }^{28)}$. The theory of the $\mathrm{XX} / \mathrm{XY}$ mosaicism in hemopoietic cells has been established in cattle ${ }^{27.28)}$.

The animal No. 4 had the XX/XY mosaicism in leukocytes and had the normal female chromosome constitution in the skin and the kidney cells. The mosaicism in the hemopoietic tissue of the animal, therefore, might be derived from the intra-uterine vascular anastomosis. This supports the hypothesis proposed by VoG ${ }^{4}$ ).

In the case No. 5 , the $\mathrm{XX} / \mathrm{XXY}$ mosaicism, the occurrence of $\mathrm{XX}$ cell line by the deletion of the $\mathrm{Y}$ chromosome during the development of an abnormal XXY zygote or the fusion of a normal XX zygote and an abnormal XXY zygote may be suggested as the cause of the mosaicism, since the animal showed the mosaicism in the hemopoietic cells, kidney cells and skin cells. This type of mosaicism has been reported in $\operatorname{man}^{29)}$ and in a tortoiseshell cat ${ }^{30)}$ but not in swine before.

The author is very grateful to Drs. T. Yoshiкawa and T. Suzuki of Tokyo Noko University for their helpful suggestions and support in this study, and also very grateful to Drs. T. Nagano and T. Chiba of Chiba University and Drs. T. Ishikawa and K. Kawata, and Y-I. Miyake M. Sc. of Hokkaido University for their careful reading and improvement of the manuscript.

\section{References}

1) Makino, S., M. S. Sasaki, T. Sofuni, and T. Ishikawa, Proc Jap Acad 38: 686-689. 1962.

2) McFee, A. F., M. Knight, and M. W. Banner, Can J Genet Cytol 8: 502-505. 1966.

3) Bruere, A. N., E. D. Fielden, and H. Hutchings, New Zealand vet J 16: 31-38. 1968.

4) VogT, D. W., J Hered 59: 166-167. 1968. 
5) Somlev, B., E. Hansen-Melander, Y. Melander, and L. Holm, Hereditas 64: 203-210. 1970.

6) Basrur, P. K., and H. Kanagawa, J Reprod Fert 26: 369-371. 1971.

7) Gluhovschi, N., M. Bistriceau, M. Rosu, and M. Bratu, Arch Vet 3: 317-333. 1967.

8) Breeuwsma, A. J., J Reprod Fert 16: 119-120. 1968.

9) Gerneke, W. H., Onderstepoort J vet Res 34: 219-300 1967.

10) HARD, W. L., and J. D. Eisen, J Hered 56: 255-258. 1965.

11) Vogt, D. W., J Anim Sci 25: 252. 1966.

12) Hard, W. L., Anat Rec 157: 255-256. 1967.

13) McFeely, R. A., W. C. D. Hare, and J. D. Biggers, Cytogenetics 6: 242-253. 1967.

14) Somlev, B., Y. Metander, E. Hansen-Melander, J. Aamdal, and K. Andersen, Hereditas 64: 296-297. 1970.

15) Backstrom, L., and B. Henricson, Acta Vet Scand 12: 257-273. 1971.

16) Melander, Y., Hereditas 69: 51-58. 1971.

17) Mryake, Y-I., Jap J vet Res 21:41-49. 1973.

18) Rothfels, K. H., and L. Siminovitch, Stain Technol 33: 73-77. 1958.

19) Gimenez-Martin, G., J. F. Lopez-Saez, and E. G. Monge, J Hered 53: 281, 290. 1962.

20) McFee, A.F., M. W. Banner, and J.M. Rary, Cytogenetics 5: 75-81. 1966.

21) Rittmanisperger, C., Wien Tieraerztl Monatsschr 57: 72-74. 1970.

22) Folger, A. F., Acta path microbiol Scand Suppl 11:143-150. 1932.

23) Hulland, T. J., Can vet J 5: 39-41. 1964.

24) Cox, J.E., J Reprod Fert 16: 321-322. 1968.

25) Hoadley, L., Anat Rec 38: 177-187. 1927.

26) Heghes, W., Anat Rec 41: 213-246. 1929.

27) Ohno, S., J. M. Trujillo, C. Stenus, L. C. Christian and R. L. Teplitz, Cytogenetics 1: 258265. 1962.

28) Ohno, S., J Reprod Fert Suppl 7: 53-61. 1969.

29) Ford, C. E., P. E. Polani, J. G. Briggs, and P. S. F. Bishop, Nature 183:1030-1032. 1959

30) Chu, E. H. Y., H.C. Tulıne, and D. E. Norby, Cytogenetics 3: 1-18 1964.

\title{
5 例の間性ブタに㧍ける性染色体モザイク
}

\author{
外山芳 郎* \\ 東京紫工大学装学部, 柬京 183
}

䦭性ブタ発生機序解明の一助乙してその染色体粠成を 調へたた，染色体標本は全例において胥制細胞および末梢 血細胞に由来する。さらに2 例において皮履および㹂の 緗胞の染色体も調ベた. 例 1：外陰部は雌型を示したが 内部生殖器は全てみられなかった，尿道は腟漛であっ た。例 2：例 1 己ほぼ同㴍な解剖所見であった，例 3 ： 外陰部には膨大した陰稯だけがみられた，管腔の狭い 胵，汪ほ正常な子宮，および精舁上体をもつ両側性の腹 腔内精单加みら九た，例 4：外險部は例 3 と似ている

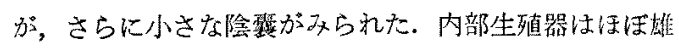
型を示し，两側性の下降した精单，精巣上体，精管，精

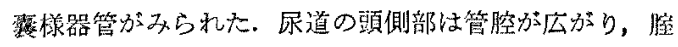

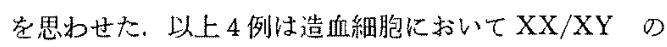
モザイクであった．例 4 の非造血細胞ではXXのみであ った．例 5：外除部は例 3 と同様であった。管腔の狭い

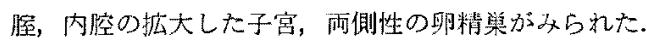
性染色体構成性造血，非造血細胞ともに XX/XXYであ った。例 4 の造血細胞における XX/XYモザイクは非造

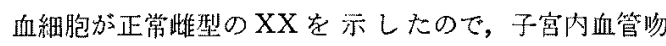
合の縝果と思われる。例 5 では䟧血，非尷血細胞ともに XX/XXYモザイクが办られたので，XXY肧の発生過 程におりるXX細胞の山現をたはXX肧とXXY脴の合 一加原因として考えられる。 